events, the existence of directional properties of the ether determined by the regular arrangement of the grains, and the finity or infinity of extent of the medium. It may be confidently. anticipated that Prof. Osborne Reynolḋs's granular medium will play an important part in the physics of the future. It is, however, to be hoped that the subject will receive careful and critical study in the hands of numerous mathematical physicists, and that it will not be left for the experimenter and philosopher blindly to accept Prof. Revnolds's doctrines as the basis of speculations about things which they do not understand. The practice of assuming statements to be true because Maxwell made them has been too prevalent in the past, and there is not very much difference between those who adopt this attitude and writers who publish papers at their own expense to show that the earth is not round or that gravitation does not exist. The dogmatic statements of the former class of philosopher often afford plenty of material for the abusive attacks of the latter.

$$
\text { G. H. BRYAN. }
$$

\section{THE EFFECT OF EDUCATION AND} LEGISLATION ON TRADE.

$\mathrm{N}$ his second presidential address to the Society of Chemical Industry at its annual meeting held in Bradford, Mr. Levinstein again addressed himself to the subject of education. He thinks that almost too much importance has been attached to education as being the only factor which has caused the industrial progress and superiority, in certain classes of merchandise, of Germany in comparison with this country. Attention is therefore directed to other considerations which he considers have also to be taken into account, such as the unification of the various German States after the Franco-German war, which, of course, gave an internal free trade to the German nation, the nationalisation of the railways and canals, and the protective patent laws.

He then refers to America, which he does not consider to be a better educated country than our own. Naturally the new Education Act of 1902 comes under review. Mr. Levinstein is doubtful, as are many others, if the Bill will advance secondary education, because the number of persons appointed to the councils who represent secondary education is excecdingly small. No remark is made upon another aspect of the case, namely, that a great many of those appointed know practically nothing about primary, and still less about secondary education. In some cases which have come before our notice, persons of little education (beyond their own inflated opinion of themselves), but desirous of local fame, and having plenty of " push," have brought themselves forward and been elected, while those who really are educated, and know what education means, have been passed by.

The raising of secondary education to a really high and uniform standard will be extremely costly. But the expenditure on primary education, according to the provisions of the new Act, will absorb such a large amount of the ratepayers' money that they will be disinclined to incur further expenditure in order to make it really efficient. No student can enter a German technical college without passing an extremely searching and thorough examination. In Great Britain the total number of students, from fifteen years and upwards, taking complete day technological courses is 3873 ; probably not more than ro per cent. could pass the entrance examination of Charlottenburg.

$\Lambda$ s an illustration of what Manchester is doing in the way of technical training, Mr. Levinstein gives an account of "the department for preparing, bleaching, dyeing, printing, mercerising and finishing textiles, together with the manufacture of paper." There is no dabbling here with manufacture in a test tube, such as we see in some of our educational institutes. The department is lodged in a separate building apart from the school of technology. It is fitted with the latest and most up-to-date machinery, taken from this country and abroad. As all the machinery is driven by separate motors, there will be no difficulty in replacing it, as it becomes out of date and obsolete, by means of newer and more modern machinery.

In this country we excel in the production of firstclass varn and cloth, made from first-class raw material. These goods will always fetch a good price. But within the last quarter of a century a demand has sprung up for cheap imitations, made from inferior materials, but which must have the external appearance of the first-class article. It is in the weighting of silk, the intermixing of fibres and the manufacture of imitation velvets that the foreigner excels. But the demand is enormous, and if we would hold our own in the markets of the world, we must learn how to manufacture these cheap goods. The British manufacturer must learn to adapt himself to the times and to the tastes and wishes of the consumer.

Manufacturers have often refused to employ chemists, except as "testing machines," because the chemist is so often only a theorist, sometimes not ever. that, and understands absolutely nothing about machinery. This excuse will, however, soon be no longer tenable. Students who have passed through the department just mentioned at the Manchester Technical School should be fully qualified to take a position not only in dye, bleach, print, mercerising, or fitushing works, but also in paper mills. They will have not only a knowledge of chemistry, but also of machinery. It is a pity that technical institutes do not make it compulsory for those who intend to become works chemists to include in the syllabus a ccurse in engineering, both practical and theoretical.

Referring to the "Patent Law Amendment Act," Mr. Levinstein has great hopes that satisfactory results will accrue to our manufacturers. The chief clause in the Act, and one for which British manufacturers have been agitating for many years, is that which deals with the granting of licences. Hitherto the foreigner could patent anything he chose, manufacture it abroad, and "dump" it down here, without his being under any obligation to manufacture it on British soil. And it was a matter of great difficulty to compel him to grant a licence to a British firm to manufacture the goods. Under the new Act, if he does not manufacture in this country, he can be compelled to grant a licence for the manufacture of the product, or failing this his patent may be declared void.

It is only after more than twenty years of agitation that this Act has been passed. Mr. Levinstein reviews the pioneering work which had to be done before the inertia of the Board of Trade was overcome.

Finally, the difficult and vexed question of foreign tariffs is dealt with. Mr. Levinstein considers that the reasons we have not made greater headway, so far as our export trade is concerned, are:-our education has been at fault, our patent laws were bad, and foreign tariffs have often been prohibitive; and we would add the want of adaptability of some of our manfacturers. The Government is also exceedingly slack in making known to our traders, at the earliest moment possible, changes in foreign tariffs. Interested Continental traders learn at once, through their Minister of Commerce, not only changes which have taken place, but changes which are contemplated. But the wheels of our Government, in respect to information which may 
be of vital importance to the traders, move so exceedingly slow. The fact is, we require a Minister of Commerce with a competent staff, and the sooner the Government awakes to the fact the better for the country.

F. Mollwo Perkin.

\section{NOTES.}

IT is probably known to some that a project has been started, and is already well advanced, to found a prize for physics at St. Peter's College, Cambridge, as à tribute to the memory of the late Prof. Tait, of Edinburgh, honorary fellow of the college. Besides members of the college who have heartily taken part in the enterprise, many friends of Prof. Tait, both in Belfast and Edinburgh, have recorded their appreciation of him and of his great services to the advancement of science by joining in this memorial of him at the college of which he was so brilliant a nember; and it is believed that others, if they were made aware of the proposal, would desire, for a like reason, to be associated with it. Mr. I. D. H. Dickson, St. Peter's College, Cambridge, will reply to any inquiries, and until more formal thanks are made by the college, will gratefully receive and acknowledge any donations that may be sent to him for the purpose of the memorial.

IT is expected that a monument to the electrician, Zenobe Gramme, will shortly be raised in Brussels. Owing to the efforts of M. Léon Janssen, the general manager of the tramways of Brussels, a committee has been appointed to accomplish this purpose.

We learn from the British Medical Journal that the proposal of the German committee of the Virchow memorial to erect a statue of Virchow in one of the public streets of Berlin, near the place where his scientific work was conducted, will be carried out. Contributions towards this memorial should be sent to the Bankhaus Mendelssohn und (ie, Berlin, W., Jägerstr. 49, 5o. An obelisk of unpolished grey granite has been placed over Virchow's grave in the old Matthäikirchof, Berlin. It bears on one side a black marble tablet, on which is inscribed "Rudolph Virchow," and the date of his birth and death.

WE regret to see the announcement of the death, in his seventy-first year, of Prof. Rudolf Lipschitz, the professor of mathematics at the University of Bonn.

THE death is announced of Prof. Alexander Rollet, of Graz, in his seventieth year. He was educated at Vienna, but was deeply influenced by Ludwig, and devoted himself especially to the physiology of the blood and muscles. He was called to Graz in 1863 , and was four times rector of that university.

A MESSAGE from Rome, through Laffan's Agency, dated October 20, states that Mount Vesuvius is again active, enormous globes of steam being emitted from the principal crater, accompanied by incessant subterranean rumblings and explosions. A stream of lava is flowing down one side of the volcano.

THe Odontological Society of Great Britain announces that it is prepared to receive applications for grants in aid of the furtherance of scientific research in connection with dentistry. For particulars and forms of application inquiry

$$
\text { NO. } 1773 \text {, VOL. 68] }
$$

should be made of the honorary secretary, Scientific Research Committee, Odontological Society, 20 Hanover Square, London, W.

The new college farm established at Madryn, midway between Aber and Llanfairfechan, in connection with the Agricultural Department of the University College of North Wales, was formally opened on October 17 by the Eari of Onslow, President of the Board of Agriculture. In the course of his inaugural address, Lord Onslow advocated the desirability of giving greater attention to forestry in this country.

FOr a long time plague has been endemic in Hong Kong; the disease reappearing after a period of intermission in an inexplicable manner. Prof. Simpson has lately pointed out in a report to the Colonial Office that domestic animals and poultry may contract plague in a latent form from feeding upon plague-infected material, and has suggested that infected food may be a potent source in disseminating the disease. According to the Tinies (October 17) Sir Henry Blake, the Governor, has recently instituted an investigation of the inhabitants and vermin of a large native quarter in the colony certified to be free from plague. This has revealed that a considerable number of the bugs, fleas, spiders and cockroaches contain plague bacilli. Samples of blood from supposed healthy natives upon examination showed the presence of plague bacilli in 5 per cent. of the speeimens. Linder favourable conditions such infected persons and vermin become possible sources of danger, and sporadic outbreaks must be expected while they are present. It is difficult also to see what measures can be taken to eradicate the disease in these circumstances.

Ix the course of the Harveian oration delivered before the Royal College of Physicians on Monday, Dr. W. H. Allchin referred to recent work on radio-activity and the constitution of matter, and its bearing on biological processes. He remarked that as the atomic and molecular theory was utilised to furnish an explanation of that flux of chemical activity which is denominated bioplasm, so have speculations on ionic action been pressed into the same service, and with some promise, wholly hypothetical as they may be. Nerve action is simply electrical action negative ions being released where nerve blends with muscle or where systems of concatenated neurons come into connection. Ion after ion is precipitated, and thus neural conduction takes place. This play of ions is excited or inhibited by the character of the fluids with which the protoplasm is bathed-by the nature, that is, of the ions which these fluids contain. Most effective in stimulating protoplasmic action are such substances as sodium salts, as those of lime restrain it, and since such inorganic bodies are among the products of tissue waste, it may be that in the ions of metabolism are to be found the causes of that rhythmic tendency to activity which nerve cell and muscle fibre alike exhibit. If normal neuro-muscular action may be thus induced, the theory offers a clue to the comprehension of some of the most obscure morbid manifestations of these tissues. In many departments of physiology, notably in that concerned with nerve and muscle and with secretion, a large mass of information has been acquired as the result of experiments, whilst but little has been done towards ascertaining the ultimate structure of the tissues concerned -little, that is, beyond what was known a score of years ago or more. In respect to such tissues as these, microscopic examination would seem almost to have reached its limits, and for the complete comprehension of the physico- 